\title{
Introduction to special issue on natural halocarbons in the atmosphere
}

\author{
Lucy J. Carpenter ${ }^{1}$ (D) Yoko Yokouchi ${ }^{2}$ Elliot L. Atlas ${ }^{3}$
}

Received: 6 April 2017 / Accepted: 13 April 2017 /

Published online: 4 May 2017

(C) Springer Science+Business Media Dordrecht 2017

Natural halocarbons are becoming increasingly accepted as important contributors to key atmospheric processes. While $\mathrm{CH}_{3} \mathrm{Cl}$, mainly from natural sources, has long been recognised as providing a significant part $(\sim 13 \%)$ of the chlorine which causes stratospheric $\mathrm{O}_{3}$ depletion, natural bromine and iodine containing compounds have been more recently acknowledged to also have an important role in destroying tropospheric $\mathrm{O}_{3}$ and contributing to stratospheric $\mathrm{O}_{3}$ loss. The increasing role of very short-lived (VSLS) chlorinated compounds, such as $\mathrm{CH}_{2} \mathrm{Cl}_{2}$ and $\mathrm{CHCl}_{3}$, in the stratosphere has been another recent example of the contribution of halocarbons to chemical budgets and reactions in the atmosphere. It has been suggested that a combination of increased halocarbon emissions and projected increases of vertical transport into the tropical stratosphere could lead to increased contributions of such compounds to halogen background levels and thus to ozone depletion (Dessens et al. 2009; Hossaini et al. 2012, 2015; Tegtmeier et al. 2012). However, the evidence base for such predictions is currently limited, with a lack of knowledge of the environmental controls of natural halogen emissions and of the contribution of natural and anthropogenic sources to halogen background levels.

In this issue, eight studies provide new information on source processes and chemistry of atmospheric halogens.

More than $60 \%$ of the global $\mathrm{CH}_{3} \mathrm{Cl}$ budget is thought to be accounted for by tropical terrestrial sources. Anthropogenic emission strengths are a large uncertainty in the global $\mathrm{CH}_{3} \mathrm{Cl}$ budget. Li. et al. present a regional estimation of industry-derived $\mathrm{CH}_{3} \mathrm{Cl}$ emissions in China and find that global anthropogenic emissions of $\mathrm{CH}_{3} \mathrm{Cl}$, which have not been regulated under the Montreal Protocol (MP) or its successor amendments, have been substantially underestimated. The oceans are a small natural source of $\mathrm{CH}_{3} \mathrm{Cl}$, arising from chemical production, macroalgal emissions, and phytoplankton. Abe et al. find that production rates

Lucy J. Carpenter

lucy.carpenter@york.ac.uk

1 Department of Chemistry, University of York, York, Heslington YO10 5DD, UK

2 National Institute for Environmental Studies, Tsukuba, Japan

3 University of Miami, RSMAS/MAC, Miami, FL 33149, USA 
of $\mathrm{CH}_{3} \mathrm{Cl}$ from the diatom $P$. tricornutum were dependent on water temperature, and increased as incubation temperature increased from 10 to $25{ }^{\circ} \mathrm{C}$. Berberich et al. measured $\mathrm{CH}_{3} \mathrm{Cl}$, $\mathrm{CHCl}_{3}$, and $\mathrm{CHBr}_{3}$ emissions from red wood ants and suggest a new route to $\mathrm{CHCl}_{3}$ via this pathway, supplementing other known terrestrial biogenic routes to formation such as termites (Khalil et al. 1990, 1999). A new photochemical route to gaseous $\mathrm{Cl}$ is proposed by Wittmar et al. which occurs when $\mathrm{HCl}$ converts to $\mathrm{Cl}$ on iron-containing aerosol particles at low $\mathrm{pH}$. These experiments indicate that iron-induced $\mathrm{Cl}$ formation may be important for highly soluble combustion-aerosol particles in marine environments in the presence of gaseous $\mathrm{HCl}$.

In a study of volatile organic iodine compounds (VOIs) in a Japanese bay, Shimizu et al. find that seasonal peaks in seawater concentrations of $\mathrm{CH}_{3} \mathrm{I}, \mathrm{C}_{2} \mathrm{H}_{5} \mathrm{I}, \mathrm{CH}_{2} \mathrm{I}_{2}$, and $\mathrm{CH}_{2} \mathrm{ClI}$ have little contribution from macro algal production but are associated with the decay of the diatom spring bloom. The authors show that $\mathrm{C}_{2} \mathrm{H}_{5} \mathrm{I}$ production is associated with bacterial degradation of organic matter produced by the bloom, and that $\mathrm{CH}_{2} \mathrm{I} 2$ and $\mathrm{CH}_{2} \mathrm{ClI}$ seawater concentrations may be associated, somewhat later in the season, with decay of the diatom spring bloom possibly via reaction of seawater DOM with $\mathrm{I}_{2} \cdot \mathrm{CH}_{2} \mathrm{I}_{2}$ and $\mathrm{CH}_{2} \mathrm{ClI}$ can be important contributors to tropospheric iodine. Carpenter et al. show that these compounds have strong diurnal cycles both in air and in surface seawater, due predominantly to their fast photolytic destruction in air and seawater. However, the data reveal an additional night-time loss of $\mathrm{CH}_{2} \mathrm{I}_{2}$, not currently accounted for in models, and speculate that a reaction with nitrate radical may be an important sink for $\mathrm{CH}_{2} \mathrm{I}_{2}$.

In contrast to VOIs, macro algae are a very important source of VSLS bromocarbons. Yokouchi et al. remarkably find that the relative concentrations of $\mathrm{CH}_{2} \mathrm{Br}_{2}$ and $\mathrm{CHBr}_{3}$ in clean marine air on a global scale could be characterised by a single chemical decay line. This supports previous suggestions that $\mathrm{CH}_{2} \mathrm{Br}_{2}$ and $\mathrm{CHBr}_{3}$ derive from a common process, and that the emission ratios of these compounds vary systematically across the oceans (Carpenter and Liss 2000). Yokouchi et al. also identified widespread bromocarbon sources in Southeast Asia, likely from multiple coastal sources (the region comprises more than ten thousand islands) from warm waters.

Ziska et al. calculate historical and future trends in sea-to-air fluxes of the VSLS $\mathrm{CH}_{2} \mathrm{Br}_{2}$, $\mathrm{CHBr}_{3}$ and $\mathrm{CH}_{3} \mathrm{I}$ from 1979 to 2100, using three CMIP5 models. Assuming constant concentration fields in the ocean and atmosphere, i.e. changes induced only via the gas transfer coefficient $k_{w}$, increases of 6-8\% are predicted to have occurred during 1979-2013, due almost entirely to increases in wind speed. For the time period 2006-2100, the multi-model mean increases for RCP 8.5 were $29 \%, 23 \%$ and $6 \%$ for $\mathrm{CHBr}_{3}, \mathrm{CH}_{2} \mathrm{Br}_{2}$, and $\mathrm{CH}_{3} \mathrm{I}$, respectively, due mainly to increases in SST which are predicted to range from 2 to $4 \mathrm{~K}$ in all latitudinal bands across all models. The actual influence of future ocean productivity changes on the oceanic halocarbon production rates and concentrations are currently unclear and need to be assessed in follow-up studies.

\section{References}

Carpenter, L.J., Liss, P.S.: On temperate sources of bromoform and other reactive organic bromine gases. J. Geophys. Res. 105, 20539-20547 (2000). doi:10.1029/2000JD900242

Dessens, O., Zeng, G., Warwick, N., Pyle, J.: Short-lived bromine compounds in the lower stratosphere; impact of climate change on ozone. Atmos. Sci. Lett. 10, 201-206 (2009). doi:10.1002/asl.236

Hossaini, R., Chipperfield, M.P., Dhomse, S., Ordonez, C., Saiz-Lopez, A., Abraham, N.L., Archibald, A., Braesicke, P., Telford, P., Warwick, N., Yang, X., Pyle, J.: Modelling future changes to the stratospheric 
source gas injection of biogenic bromocarbons. Geophys. Res. Lett. 39, L20813 (2012). doi:10.1029/2012 GL053401

Hossaini, R., Chipperfield, M.P., Montzka, S.A., Rap, A., Dhomse, S., Feng, W.: Efficiency of short-lived halogens at influencing climate through depletion of stratospheric ozone. Nat. Geosci. 8, 186-190 (2015). doi:10.1038/ngeo2363

Khalil, M.A.K., Rasmussen, R.A., French, J.R.J., Holt, J.A.: The influence of termites on atmospheric trace gases: CH4, CO2, CHC13, N2O, CO, H2, and light hydrocarbons. J. Geophys. Res. Atmos. 95, 3619-3634 (1990)

Khalil, M.A.K., Moore, R.M., Harper, D.B., Lobert, J.M., Erickson, D.J., Koropalov, V., Sturges, W.T., Keene, W.C.: Natural emissions of chlorine-containing gases: reactive chlorine emissions inventory. J. Geophys. Res.-Atmos. 104, 8333-8346 (1999)

Tegtmeier, S., Krüger, K., Quack, B., Atlas, E.L., Pisso, I., Stohl, A., Yang, X.: Emission and transport of bromocarbons: from the West Pacific ocean into the stratosphere. Atmos. Chem.Phys. 12, 10633-10648 (2012). doi:10.5194/acp-12-10633-2012 